\title{
Copper Isotopic Analysis in Geological and Biological Reference Materials by MC-ICP-MS
}

\author{
Kaj Sullivan (1, 2) (D), Daniel Layton-Matthews (2), Matthew Leybourne (2), James Kidder (2), \\ Zoltán Mester (1) and Lu Yang (1)* \\ (1) National Research Council Canada, 1200 Montreal Road, Ottawa, KIA OR6, Canada \\ (2) Department of Geological Sciences and Geological Engineering, Queen's University, 36 Union Street, K7L 2N8, Kingston, Canada \\ * Corresponding author. e-mail: Lu.Yang@nrc-cnrc.gc.ca
}

The characterisation of relative copper isotope amount ratios $\left(\delta^{65} \mathrm{Cu}\right)$ helps constrain a variety of geochemical processes occurring in the geosphere, biosphere and hydrosphere. The accurate and precise determination of $\delta^{65} \mathrm{Cu}$ in matrix reference materials is crucial in the effort to validate measurement methods. With the goal of expanding the number and variety of available geological and biological materials, we have characterised the $\delta^{65} \mathrm{Cu}$ values of ten reference materials by MC-ICP-MS using C-SSBIN model for mass bias correction. SGR-1b (Green River shale), DOLT-5 (dogfish liver), DORM-4 (fish protein), TORT-3 (lobster hepatopancreas), MESS-4 (marine sediment) and PACS-3 (marine sediment) have for the first time been characterised for $\delta^{65} \mathrm{Cu}$. Additionally, four reference materials (with published $\delta^{65} \mathrm{Cu}$ values) have been characterised: BHVO-1 (Hawaiian basalt), BIR-1 (Icelandic basalt), W-2a (diabase) and Seronorm ${ }^{\mathrm{TM}}$ Trace Elements Serum L-1 (human serum). The reference materials measured in this study possess complex and varied matrices with copper mass fractions ranging from $1.2 \mu \mathrm{g} \mathrm{g}^{-1}$ to $497 \mu \mathrm{g} \mathrm{g}^{-1}$ and $\delta^{65} \mathrm{Cu}$ values ranging from $-0.20 \%$ to $0.52 \%$ o with a mean expanded uncertainty of $\pm 0.07 \%(U, k=2)$, covering much of the natural copper isotope variability observed in the environment.

Keywords: non-traditional stable isotopes, $\delta^{65} \mathrm{Cu}$, anion exchange chromatography, MC-ICP-MS, mass bias, reference materials.

Received 05 Nov 19 - Accepted 16 Jan 20

The transition metal element copper (Cu) consists of two stable isotopes, ${ }^{65} \mathrm{Cu}$ and ${ }^{63} \mathrm{Cu}$, and is an important element for studying reduction-oxidation (redox) interactions and metal cycling in the geosphere, hydrosphere and biosphere (Moynier et al. 2017). It is also an essential trace element for the functioning organs and metabolic processes in plants (Yruela 2005) and animals (Uauy et al. 1998). Copper takes part in important redox reactions in the environment, shifting between two oxidation states, $\mathrm{Cu}^{+}$and $\mathrm{Cu}^{2+}$, allowing it to act as both an electron donor and acceptor. As an essential trace element in most aerobic organisms, Cu is a useful tool for studying biological processes with their short turnover rates and specific functional roles in biology (Kim et al. 2008, Albarède et al. 2017). Copper isotope amount ratio measurements were first performed in the 1950s and 1960s, using thermal ionisation mass spectrometry (TIMS), but there was difficulty achieving reproducible data of sufficient precision not to completely obscure natural isotopic variations (Walker et al. 1958, Shields et al. 1965, Gale et al. 1999). It was only with the development of MC-ICP-MS and anion exchange column chromatography procedures capable of sufficiently purifying low quantities of $\mathrm{Cu}$ from complex matrices prior to isotopic analysis that we have been able to resolve subtle changes in $\mathrm{Cu}$ isotope amount ratios in the environment (Maréchal et al. 1999).

Most recently, the measurement of relative $\mathrm{Cu}$ isotope ratios $\left(\delta^{65} \mathrm{Cu}\right)$ in the human body by MC-ICP-MS has gained increased interest, and research suggests $\mathrm{Cu}$ isotopes have potential uses in monitoring age (Jaoven et al. 2013), sex (Jaouen et al. 2012, Van Heghe et al. 2014, Jaouen et al. 2017), diet (Van Heghe et al. 2014, Jaouen et al. 2017), disease pathologies (Aramendía et al. 2013, Balter et al. 2015, Costas-Rodríguez et al. 2015, Télouk et al. 2015, Lauwens et al. 2016, Sauzéat et al. 2018, Miller et al. 2019, Moynier et al. 2019) and other biological processes (Albarède et al. 2011, Jaoven and Balter 2014, Van Heghe et al. 2014, Cadiou et al. 2017, 
Flórez et al. 2018). Of the investigated human biological materials, serum is the most extensively studied, being chemically stable, inexpensive and minimally invasive to obtain. Copper in serum has a rapid turnover rate of 6 weeks (Linder and Goode 1991, Milne 1998), making it optimal for monitoring rapidly progressing disease pathologies. This makes it the most convenient material to work with as any relationships discovered with pathologies could be routinely monitored with minimal discomfort to the patients. Copper isotopes in groundwater are also now being explored as potential vectors of covered mineral deposits (Asael et al. 2007, Borrok et al. 2007, Mathur et al. 2013, 2014, Townley et al. 2015), and a means of tracking its biological cycling in past and present oceans using seawater and leachable fractions of marine sediments (Bermin et al. 2006, Little et al. 2014). Copper isotopes may also be used to trace high temperature magmatic processes (Liv et al. 2014) and study mantle metasomatism and partial melting in distinct silicate reservoirs on Earth (Liv et al. 2015).

Direct comparison of $\mathrm{Cu}$ isotope amount ratios in samples with NIST SRM 976 is becoming increasingly difficult due to its limited availability. For this reason, NIST SRM 976 was calibrated against ERM ${ }^{\circledR}$-AE633 and ERM ${ }^{\circledR}$ AE647 that are certified for isotope amount ratios (Moeller et al. 2012). While ERM ${ }^{\circledR}-A E 647$ is still commercially available, ERM ${ }^{\circledR}$-AE633 has been discontinued. Thus, new Cu isotopic reference materials calibrated against NIST SRM 976 must be continually developed to enable the interlaboratory comparison of results. Recently, the NIST SRM 3114 $\mathrm{Cu}$ standard solution was investigated as a candidate $\mathrm{Cu}$ isotopic nce material, but disagreeing results within reported uncertainties were obtained by two research groups with Hou et al. (2016) reporting a $\delta^{65} \mathrm{Cu}$ value of $0.18 \pm 0.04 \%$ $(2 s, n=5)$ and Baconnais et al. (2019) reporting a $\delta^{65} \mathrm{Cu}$ value of $-0.06 \pm 0.02 \%$ o $(2 s, n=44)$. This study will examine the isotopic homogeneity of a purified $\mathrm{Cu}$ wire (99.999\% Cu), henceforth referred to as 'HICU-1', a candidate $\mathrm{Cu}$ isotopic CRM produced at National Research Council Canada (NRC, Ottawa, Canada), and determine its Cu isotope amount ratio relative to NIST SRM 976 and ERMAE647, respectively.

The ability to perform high precision measurements of $\mathrm{Cu}$ isotope amount ratios in geological and biological materials is reliant on both the capability of quantitatively separating $\mathrm{Cu}$ from complex matrices enriched in elements like sodium ( $\mathrm{Na}$ ) and titanium (Ti) that form prominent polyatomic interferences in the plasma of MC-ICP-MS instruments, and correcting for instrumental mass bias, due to the preferential transmission of higher mass isotopes to detectors (Gillson et al. 1988, Heumann et al. 1998). This study further adapts methods developed by Maréchal et al. (1999) and Hou et al. (2016) to purify Cu from matrix elements using the Bio-Rad AG ${ }^{\circledR}$ MPIM (100-200 mesh) resin. A combined standard-sample bracketing (SSB) and internal normalisation (C-SSBIN) mass bias correction using Ga as an internal standard was selected to correct for instrumental mass bias after successful implementation first by Hou et al. (2016) and by Lauwens et al. (2018), as it provides a better measurement uncertainty (Yang et al. 2018). Other calibrants such as a Zn (Maréchal et al. 1999) or Ni (Ehrlich et al. 2004) can be used.

The determination of $\mathrm{Cu}$ isotope amount ratios in matrix reference materials is crucial in the effort to validate measurements performed on new samples. Commonly, isotope studies only run pure, single-element standards through column chemistry procedures alongside samples to validate the results of their measurements performed on samples with complex matrices. This is insufficient to validate measurements of these new materials as producing expected $\mathrm{Cu}$ isotope amount ratios in pure, single-element standards only indicates high quality Cu yield and minimal blank contribution, and not quality of the separation from interfering elements. The measurement of matrix reference materials alongside samples is crucial for verifying that a chromatography procedure can sufficiently purify Cu from a given matrix. For example, a material containing high quantities of $\mathrm{Cu}$ with low amounts of interfering elements will have a much lower contaminant-to-Cu ratio than one containing low levels of $\mathrm{Cu}$ relative to $\mathrm{Na}$. This is the case for serum, in which $\mathrm{Na}$ is typically 3000 times more concentrated than $\mathrm{Cu}$ (Harrington et al. 2014). For example, if $0.5 \mathrm{~g}$ of human serum were digested and put through a chromatography procedure that yielded $100 \%$ of $\mathrm{Cu}$ and removed $99.9 \%$ of $\mathrm{Na}, 1.5 \mu \mathrm{g}$ of $\mathrm{Na}$ would still remain with the eluted $0.5 \mu \mathrm{g}$ of $\mathrm{Cu}$. This would give a $\mathrm{Na} / \mathrm{Cu}$ ratio of 3 , which is well within the range where the formation of ${ }^{23} \mathrm{Na}^{40} \mathrm{Ar}^{+}$in the plasma could lead to a falsely lower ${ }^{65} \mathrm{Cu} /{ }^{63} \mathrm{Cu}$ ratio (Liv et al. 2014, Hou et al. 2016). Conversely, this would be less of an issue with a basalt such as $\mathrm{BHVO}-1$ which, despite containing much more $\mathrm{Na}$ per gram of material, has much lower $\mathrm{Na} / \mathrm{Cu}$ ratio due to containing significantly higher amounts of Cu (Verma et al. 2017).

With the goal of expanding the number and variety of available geological and biological materials with which the isotope geochemistry community can validate their $\mathrm{Cu}$ isotopic analysis, we have determined $\delta^{65} \mathrm{Cu}$ of six commercially available, previously uncharacterised materials, comprising DOLT-5 (dogfish liver), DORM-4 (fish protein), TORT-3 (lobster hepatopancreas), MESS-4 (marine sediment), PACS-3 (marine sediment) and SGR-1b (shale). We also report measurements for two basalts (BHVO-1, BIR-1), diabase (W2a) and human serum (Seronorm ${ }^{\text {TM }}$ Trace Elements Serum L-1). 


\section{GEOSTANDARDS and GEOANALYTICAL}

\section{Experimental}

\section{Instrumentation}

Copper isotope amount ratio measurements were performed on a Thermo Scientific Neptune Plus MC-ICPMS at National Research Council Canada (NRC). The MCICP-MS is equipped with nine Faraday cups, a quartz dual cyclonic spray chamber and a PFA self-aspirating nebuliser (Elemental Scientific, Omaha, NE, USA) with $\sim 50 \mu \mathrm{min}^{-1}$ sample uptake rate. All $\mathrm{Cu}$ isotope amount ratio measurements were performed at low-resolution mode. The instrument was tuned to obtain flat-top square peaks with high and stable signals. The gain calibration of the Faraday cups was performed weekly, and typical operating conditions are presented in Table 1. In addition, a virtual amplifier function was activated (through software control) during the ratio measurements to eliminate any bias in gain calibration. A Thermo Scientific Element XR High-Resolution ICP-MS was used for semi-quantitative analysis of $\mathrm{Cu}$ yields and calibration of the $\mathrm{Cu}$ anion exchange column chromatography method.

\section{Reagents and materials}

Reagent-grade hydrochloric $(\mathrm{HCl})$ and nitric acids $\left(\mathrm{HNO}_{3}\right)$ were prepared by sub-boiling distillation using a DST-1000 acid purification system (Savillex®). High purity deionised water $(18 \mathrm{M} \Omega \mathrm{cm}$ ) was prepared from a Milli-Q

Table 1.

MC-ICP-MS operating conditions

\begin{tabular}{|c|c|}
\hline Parameter & Instrument settings \\
\hline $\begin{array}{l}\text { Forward power } \\
\text { Plasma gas flow rate }(\mathrm{Ar}) \\
\text { Auxiliary gas flow rate }(\mathrm{Ar}) \\
\text { Carrier gas flow rate }(\mathrm{Ar}) \\
\text { Sampler cone orifice }(\mathrm{Ni}) \\
\text { Skimmer cone orifice }(\mathrm{H}, \mathrm{Ni}) \\
\text { Lens settings }\end{array}$ & 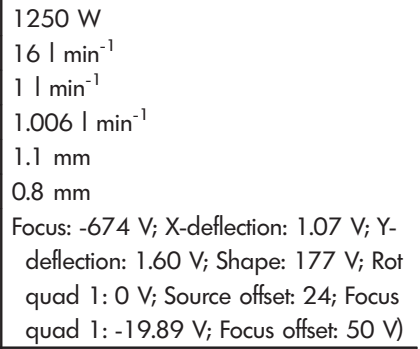 \\
\hline & Data acquisition parameters \\
\hline Faraday cup configuration & $\begin{array}{l}\text { L3 }\left({ }^{63} \mathrm{Cu}\right), \mathrm{L} 2\left({ }^{65} \mathrm{Cu}\right), \mathrm{C}\left({ }^{67} \mathrm{Zn}\right), \mathrm{H} 2\left({ }^{69} \mathrm{Ga}\right), \\
\text { H3 }\left({ }^{71} \mathrm{Ga}\right)\end{array}$ \\
\hline Zoom optics & Focus quad: $0 \mathrm{~V}$; Dispersion quad: $0 \mathrm{~V}$ \\
\hline Sensitivity & $\begin{array}{l}1 \mu \mathrm{g} \mathrm{g}^{-1} \mathrm{Cu}=8.5 \mathrm{~V}\left({ }^{63} \mathrm{Cu}\right) ; 1 \mu \mathrm{g} \\
\mathrm{g}^{-1} \mathrm{Ga}=18 \mathrm{~V}\left({ }^{69} \mathrm{Ga}\right)\end{array}$ \\
\hline Blank signal $\left(2 \% \mathrm{HNO}_{3}\right)$ & $0.008 \vee^{63} \mathrm{Cu}_{\mathrm{u}} ; 0.007 \mathrm{~V}^{69} \mathrm{Ga}$ \\
\hline Signal integration time & $2.097 \mathrm{~s}$ \\
\hline $\begin{array}{l}\text { No. of integrations, blocks, } \\
\text { cycles/block }\end{array}$ & $1,5,10$ \\
\hline
\end{tabular}

water system (Millipore Corporation). All samples were handled in Savillex® containers that were cleaned in $2 \mathrm{~mol} \mathrm{l}^{-1} \mathrm{HNO}_{3}$ and de-ionised water prior to use. Hydrogen peroxide $\left(\mathrm{H}_{2} \mathrm{O}_{2}\right)$ was purchased from Seastar Chemicals Inc.

Copper chromatography was performed using the AG

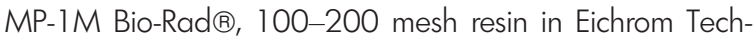
nologies Inc. columns (Part No: AC-141-AL) with a resin bed length of $1.6 \mathrm{~cm}$, column internal diameter of $0.64 \mathrm{~cm}$ and resin bed volume of $0.5 \mathrm{ml}$.

The production of isotopic certified reference material (CRM) is one of NRC's important activities, and copper isotopic CRM project was initiated in February 2017. A large quantity of 2000 units (last for decades) of the candidate copper isotopic CRM, named HICU-1, were produced from a high purity $2.4 \mathrm{~mm}$ diameter copper wire (99.999\% Cu), which was cut in $22 \mathrm{~mm}$ length and bottled in argon filled glass bottles in Mar. 2017. Each unit contains about $0.9 \mathrm{~g}$ of copper wire. The HICU-1 was used as a bracketing calibrator in this study. The surface of each was cleaned by rinsing with $5 \% \mathrm{v} / \mathrm{V}$ nitric acid $\left(\mathrm{HNO}_{3}\right)$ before being dissolved in a few millilitres of concentrated $\mathrm{HNO}_{3}$ under mild heating and then diluted to $100 \mathrm{~g}$ with de-ionised water. An aliquot of each piece was further diluted in $30 \mathrm{~g}$ of $2 \% \mathrm{v} / \mathrm{v} \mathrm{HNO}_{3}$, creating twelve $\sim 100 \mu \mathrm{g} \mathrm{g}^{-1} \mathrm{Cu}$ solutions. A Cu stock solution ( $\mathrm{HICU}-1)$ was created by combining $2 \mathrm{~g}$ of solution from each of the twelve $\mathrm{Cu}$ solutions. An aliquot of this solution was then diluted in $30 \mathrm{~g}$ of $2 \% \mathrm{v} / \mathrm{v} \mathrm{HNO}_{3}$ to create a $100 \mu \mathrm{g} \mathrm{g} \mathrm{g}^{-1}$ Cu mixture of all twelve bottles with which to compare the homogeneity of each original piece of $\mathrm{Cu}$ wire.

Gallium metal isotopic reference material, NIST SRM 994, with certified value of ${ }^{69} \mathrm{Ga} /{ }^{71} \mathrm{Ga}=1.50676 \pm$ 0.00039 (95\% confidence interval uncertainty) (Machlan et al. 1986 and NIST Ga certificate, 1986), was purchased from National Institute of Standards and Technology (Gaithersburg, MD). A $1500 \mu \mathrm{g} \mathrm{g}^{-1}$ stock solution of NIST SRM 994 was prepared by quantitative dissolution of $\mathrm{Ga}$ in warm concentrated nitric acid and then diluted with deionised water. NIST SRM 994 Ga was added to the purified copper solutions and bracketing calibrator to correct mass bias using C-SSBIN. A $3200 \mu \mathrm{g} \mathrm{g}^{-1}$ stock solution of NIST SRM $976 \mathrm{Cu}$ isotopic material was prepared in 5\% v/v $\mathrm{HNO}_{3}$, and a $1300 \mu \mathrm{g} \mathrm{g}^{-1} \mathrm{Cu}$ standard solution was prepared by dilution of ERM ${ }^{\circledR}$-AE647 (obtained from Institute for Reference Materials and Measurements (IRMM), Geel, Belgium), in $2 \% v / v \mathrm{HNO}_{3}$.

Geological reference materials BIR-1, BHVO-1, SGR-1 b and W-2a were purchased from the United States 
Geological Sunvey (USGS), and Seronorm ${ }^{\text {TM }}$ Trace Elements Serum L-1 (lot 1309438) was purchased from SERO AS (Billingstad, Nonway). The remaining reference materials DOLT-5, DORM-4, TORT-3, MESS-4 and PACS-3 were produced at NRC. Two bottles of each NRC reference materials, possessing different lot numbers, were analysed to examine their isotopic homogeneity and subsequent suitability as an isotopic reference material. From each bottle, two to three aliquots were digested, and $\mathrm{Cu}$ isotopic analysis performed.

Two synthetic serum standards of different $\mathrm{Cu}$ mass fractions $\left(9.9 \mu \mathrm{g} \mathrm{g}^{-1}\right.$ and $\left.0.6 \mu \mathrm{g} \mathrm{g}^{-1}\right)$ were prepared gravimetrically from $99.99 \%$ to $99.9999 \%$ purity calcium $(\mathrm{Ca})$, iron ( $\mathrm{Fe})$, magnesium $(\mathrm{Mg})$, potassium $(\mathrm{K})$, $\mathrm{Na}$ and zinc (Zn) single-element standards (SPEX CertiPrep $\left.{ }^{\circledR}\right)$ and $\mathrm{Cu}$ from HICU-1 (Table 2). These high-Na, complex matrix synthetic standards were used to monitor the quality of separation during isotopic analysis by MC-ICP-MS.

\section{Geological and biological sample preparation and analysis}

All samples were prepared in a class-100 clean room laboratory at NRC under laminar flow hoods with HEPAfiltered air. Geological samples ( $0.25 \mathrm{~g}$ ) were mixed with $7.5 \mathrm{ml}$ of concentrated $\mathrm{HNO}_{3}$ and $1 \mathrm{ml}$ of concentrated $\mathrm{HF}$, whereas biological samples $(\sim 0.25-0.50 \mathrm{~g})$ were mixed with $8 \mathrm{ml}$ of concentrated $\mathrm{HNO}_{3}$ and $0.5 \mathrm{ml}$ of $30 \% \mathrm{H}_{2} \mathrm{O}_{2}$ and allowed to stand for $2 \mathrm{~h}$ before being microwave digested for $55 \mathrm{~min}$, ramping up to a temperature of $210{ }^{\circ} \mathrm{C}$. After digestion, the contents of the microwave tubes were poured into Savillex ${ }^{\circledR}$ containers and evaporated to dryness on a hotplate at $160^{\circ} \mathrm{C}$. Samples were then redissolved in varying volumes of $7.6 \mathrm{~mol}^{-1} \mathrm{HCl}$ to ensure that $1 \mathrm{ml}$ of solution (load volume) was within less than 6\% of the theoretical exchange capacity of the AG MP-1M resin (Sossi et al. 2015). Prior to performing anion exchange column chromatography, a volume of $30 \% \mathrm{H}_{2} \mathrm{O}_{2}$ was

\section{Table 2.}

Composition of synthetic serum reference materials

\begin{tabular}{l|c|c}
\hline Element & $\begin{array}{c}\text { Low Cu synthetic } \\
\text { serum }\left(\boldsymbol{\mu} \mathbf{g ~ g}^{-1}\right)\end{array}$ & $\begin{array}{c}\text { High Cu synthetic } \\
\text { serum }\left(\boldsymbol{\mu g} \mathbf{~ g}^{-1}\right)\end{array}$ \\
\hline $\mathrm{Fe}$ & 0.5 & 0.5 \\
$\mathrm{Cu}$ & 0.6 & 9.9 \\
$\mathrm{Zn}$ & 0.5 & 0.5 \\
$\mathrm{Na}$ & 1479.3 & 1548.7 \\
$\mathrm{~K}$ & 88.8 & 92.6 \\
$\mathrm{Mg}$ & 11.1 & 11 \\
$\mathrm{Ca}$ & 44.5 & 47.5 \\
\hline
\end{tabular}

added to each sample to ensure it made up $0.03 \%$ of the solution, keeping $\mathrm{Cu}$ in the oxidised state.

Copper was purified from matrix elements using the AG MP-1M resin and a methodology modified after Maréchal et al. (1999), who used $7 \mathrm{~mol} \mathrm{l}^{-1} \mathrm{HCl}$, and Hou et al. (2016) who used $8.5 \mathrm{~mol} \mathrm{l}^{-1} \mathrm{HCl}$ to load samples onto columns. In this study, the most efficient separation from major matrix elements ( $\mathrm{Ca}, \mathrm{K}, \mathrm{Mg}, \mathrm{Na}$ and $\mathrm{Ti}$ ) was achieved using $7.6 \mathrm{~mol} \mathrm{l}^{-1} \mathrm{HCl}$ to load samples. Columns were filled with $0.5 \mathrm{ml}$ of resin and then cleaned by filling each column to capacity (including the upper reservoir) sequentially with $2 \mathrm{~mol} \mathrm{l}^{-1} \mathrm{HNO}_{3}$ and $2 \mathrm{~mol} \mathrm{l}^{-1} \mathrm{HCl}$, and then de-ionised water prior to conditioning with $2 \mathrm{ml}$ of $7.6 \mathrm{~mol} \mathrm{l}^{-1}$ $\mathrm{HCl}+0.03 \% \mathrm{H}_{2} \mathrm{O}_{2}$. Samples were loaded onto columns in $1 \mathrm{ml} 7.6 \mathrm{~mol} \mathrm{I}^{-1} \mathrm{HCl}+0.03 \% v / v \mathrm{H}_{2} \mathrm{O}_{2}$ and matrix elements removed with a subsequent $2 \mathrm{ml}$ of $7.6 \mathrm{~mol} \mathrm{l}^{-1}$ $\mathrm{HCl}+0.03 \% \quad v / v \mathrm{H}_{2} \mathrm{O}_{2}$ before $\mathrm{Cu}$ was eluted and collected by passing another $15 \mathrm{ml}$ of $7.6 \mathrm{~mol} \mathrm{l}^{-1}$ $\mathrm{HCl}+0.03 \% v / v \mathrm{H}_{2} \mathrm{O}_{2}$ through columns. The majority of matrix elements (e.g., $\mathrm{Na}, \mathrm{Mg}, \mathrm{K}, \mathrm{Ca}$ and $\mathrm{Ti}$ ) were eluted in the first $3 \mathrm{ml}$ but Fe and $\mathrm{Zn}$ were retained on the column throughout the separation procedure. Reference materials were processed through the chromatography procedure twice with the exception of Seronorm ${ }^{\text {TM }}$ Trace Elements Serum L-1, which was processed three times due to the high $\mathrm{Na} / \mathrm{Cu}$ ratio naturally found in human serum. The full chromatography procedure is summarised in Table 3, and the Cu elution profile is visualised in Figure 1.

Copper yield was estimated using two methods. Semiquantitatively, Cu yield was estimated to be greater than 99\% based on elution data (Figure 1), and quantitatively, Cu yield was determined to be $100.9 \pm 2.3 \%(1 s, n=3)$ by comparing the $\mathrm{Cu}$ intensities of column-processed and unprocessed samples by Element XR High-Resolution ICPMS. Total procedure blank Cu contributions were no greater than $1.3 \mathrm{ng}$ and represented less than $0.5 \%$ of Cu loaded onto columns for all reference materials.

Titanium and $\mathrm{Na}$ are the primary matrix elements that can generate polyatomic interferences with ${ }^{23} \mathrm{Na}^{40} \mathrm{Ar}^{+}$, ${ }^{23} \mathrm{Na}_{2}{ }^{16} \mathrm{O}^{1} \mathrm{H}, \quad{ }^{23} \mathrm{Na}_{2}{ }^{18} \mathrm{O}^{1} \mathrm{H}^{+}, \quad{ }^{47} \mathrm{Ti}^{16} \mathrm{O}^{+}, \quad{ }^{46} \mathrm{Ti}^{16} \mathrm{O}^{1} \mathrm{H}^{+}$, ${ }^{49} \mathrm{Ti}^{16} \mathrm{O}^{+},{ }^{48} \mathrm{Ti}^{16} \mathrm{O}^{1} \mathrm{H}^{+}$on ${ }^{63} \mathrm{Cu}$ and ${ }^{65} \mathrm{Cu}$ and cause matrix effects ( $\mathrm{Hou}$ et al. 2016). Titanium and $\mathrm{Na}$ signals were monitored by ICP-MS to determine Ti/Cu and $\mathrm{Na} / \mathrm{Cu}$ ratios and ensure they remained within acceptable levels. The Ti/Cu ratio ranged from 0.003 to 0.011 in high Ti BIR- 1 and $\mathrm{BHVO}$, with a mean of 0.007 , well below the range where significant polyatomic interferences occur on ${ }^{63} \mathrm{Cu}$ and ${ }^{65} \mathrm{Cu}$ (Liv et al. 2014, Hou et al. 2016). The $\mathrm{Na} / \mathrm{Cu}$ ratio ranged from 0.011 to 0.110 with a mean of 0.045 , also well below 


\section{GEOSTANDARDS and GEOANALYTICAL}

Table 3.

Column procedure using AG MP-1M Bio-Rad resin adapted after Hou et al. (2016)

\begin{tabular}{|c|c|c|}
\hline $\begin{array}{l}\text { Separation } \\
\text { step }\end{array}$ & Reagent & Volume (ml) \\
\hline Cleaning 1 & $2 \mathrm{~mol} \mathrm{l}^{-1} \mathrm{HNO}_{3}$ & To capacity (about $4 \mathrm{ml}$ ) \\
\hline Cleaning 2 & $2 \mathrm{~mol} \mathrm{l}^{-1} \mathrm{HCl}$ & To capacity (about $4 \mathrm{ml}$ ) \\
\hline Cleaning 3 & High purity $\mathrm{H}_{2} \mathrm{O}$ (Milli-Q) & To capacity (about $4 \mathrm{ml}$ ) \\
\hline Conditioning & $\begin{array}{l}7.6 \mathrm{~mol} \mathrm{l}^{-1} \mathrm{HCl}+0.03 \% \\
\mathrm{H}_{2} \mathrm{O}_{2}\end{array}$ & 2 \\
\hline Sample load & $\begin{array}{l}7.6 \mathrm{~mol} \mathrm{l}^{-1} \mathrm{HCl}+0.03 \% \\
\mathrm{H}_{2} \mathrm{O}_{2}\end{array}$ & 1 \\
\hline Matrix elution & $\begin{array}{l}7.6 \mathrm{~mol} \mathrm{l}^{-1} \mathrm{HCl}+0.03 \% \\
\mathrm{H}_{2} \mathrm{O}_{2}\end{array}$ & 2 \\
\hline Cu elution & $\begin{array}{l}7.6 \mathrm{~mol} \mathrm{l}^{-1} \mathrm{HCl}+0.03 \% \\
\mathrm{H}_{2} \mathrm{O}_{2}\end{array}$ & 15 \\
\hline
\end{tabular}

the range where significant polyatomic interferences begin to show on ${ }^{63} \mathrm{Cu}$ and ${ }^{65} \mathrm{Cu}$ (Liu et al. 2014, Hou et al. 2016).

After undergoing chemical separation, purified $\mathrm{Cu}$ solutions were evaporated to dryness at $160{ }^{\circ} \mathrm{C}$ and refluxed twice in $50 \mu \mathrm{l}$ of concentrated $\mathrm{HNO}_{3}$ to remove chloride ions and convert them to the nitrate form for isotopic analysis (Maréchal et al. 1999). Samples were diluted in 2\% $v / v \mathrm{HNO}_{3}$, such that $\mathrm{Cu}$ mass fractions in samples and the bracketing calibrator were matched to within $10 \%$, and then doped with NIST SRM 994 such that Ga mass fractions in samples and the bracketing calibrator were also matched to within 10\% to ensure accurate isotope amount ratio measurements (Liu et al. 2014, Yang et al. 2018). Samples and the bracketing calibrator were typically matched at $2 \mu \mathrm{g} \mathrm{g}^{-1} \mathrm{Ga}$, and $\mathrm{Cu}$ isotope measurements were performed at $\mathrm{Cu}$ mass fractions ranging from $0.25 \mu \mathrm{g} \mathrm{g}$ to $4 \mu \mathrm{g} \mathrm{g}^{-1}$, depending on the amount of $\mathrm{Cu}$ in each reference material. Note that intensities measured in a $2 \%$ $\mathrm{HNO}_{3}$ for all isotopes of interest were subtracted from intensities measured in all bracketing calibrators and samples. Lauwens et al. (2018) reported ${ }^{36} \mathrm{Ar}^{16} \mathrm{O}_{2}{ }^{1} \mathrm{H}^{+}$ and ${ }^{40} \mathrm{Ar}^{15} \mathrm{~N}^{16} \mathrm{O}^{+}$polyatomic interferences on ${ }^{69} \mathrm{Ga}^{+}$and ${ }^{71} \mathrm{Ga}^{+}$isotopes in much lower mass fractions of $\mathrm{Ga}$ $\left(<20 \mathrm{ng} \mathrm{g}^{-1}\right)$. But, no significant polyatomic interferences of ${ }^{36} \mathrm{Ar}^{16} \mathrm{O}_{2}{ }^{1} \mathrm{H}^{+}$and ${ }^{40} \mathrm{Ar}^{15} \mathrm{~N}^{16} \mathrm{O}^{+}$on ${ }^{69} \mathrm{Ga}^{+}$and ${ }^{71} \mathrm{Ga}^{+}$ isotopes, respectively, were observed in the testing samples containing $2 \mu \mathrm{g} \mathrm{g}^{-1} \mathrm{Ga}$ in this study, as only $0.00036 \mathrm{~V}$ and $0.00023 \mathrm{~V}$ were measured in the $2 \% \mathrm{HNO}_{3}$ (which were subtracted from all testing samples), compared with $34.44 \mathrm{~V}$ and $24.33 \mathrm{~V}$ in the testing solutions.

\section{Results and discussion}

\section{Mass bias correction using C-SSBIN}

Combined standard-sample bracketing and internal normalisation (C-SSBIN) using NIST SRM $994 \mathrm{Ga}$ as an internal standard model was used to correct for instrumental mass bias of $\mathrm{Cu}$ after Hou et al. (2016). Sample measurements were bracketed with measurements of $\mathrm{HICU}-1$, and a ${ }^{65} \mathrm{Cu} /{ }^{63} \mathrm{Cu}$ ratio of 0.44561 ( $R_{\mathrm{HICU}-1}^{65 / 63}$ ) was used to calculate the $\mathrm{Cu}$ mass bias factor ( $f^{\mathrm{Cu}}$ ) between it and the ${ }^{65} \mathrm{Cu} /{ }^{63} \mathrm{Cu}$ ratio measured $\left(r_{\text {HICU-1 }}^{65 / 63}\right)$ in each HICU-1 bracketing calibrator with $m_{x x}$ being the atomic mass of each isotope of interest (Equation 1). This mass bias correction factor and the measured ${ }^{71} \mathrm{Ga} /{ }^{69} \mathrm{Ga}$ ratio $\left(r_{\text {HICU-1 }}^{71 / 69}\right)$ were used to calculate the mass bias corrected isotope amount ratios of ${ }^{71} \mathrm{Ga} /{ }^{69} \mathrm{Ga}$ in each bracketing calibrator $\left(R_{\mathrm{HICU}-1}^{71 / 69}\right)$ using Russell's law (Equation 2) (Ingle et al. 2003, Pichat et al. 2003). The mean of the mass bias corrected ${ }^{71} \mathrm{Ga} /{ }^{69} \mathrm{Ga}$ isotope amount ratios in the bracketing calibrators and the

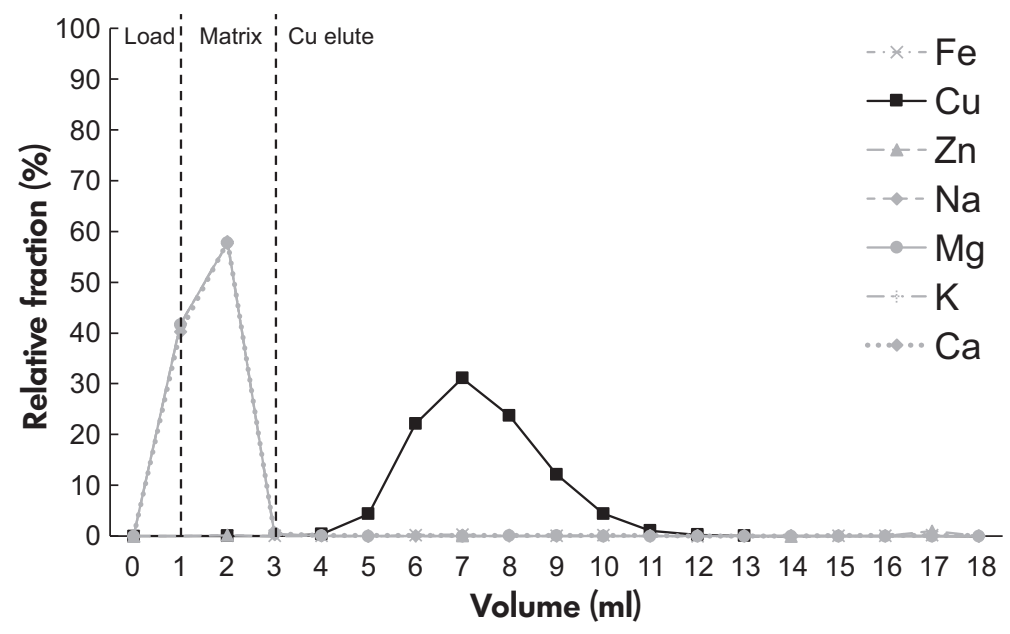

Figure 1. Elution profile of $\mathrm{Cu}$-anion exchange column chromatography method employed in this study. 
${ }^{71} \mathrm{Ga} /{ }^{69} \mathrm{Ga}$ isotope amount ratio measured in the sample $\left(r_{\text {sample }}^{71 / 69}\right)$ were then used to calculate the Ga mass bias correction factor ( $f \mathrm{Ga}$, Equation 3), which, along with the ${ }^{65} \mathrm{Cu} /{ }^{63} \mathrm{Cu}$ isotope amount ratio measured in the sample $\left(r_{\text {sample }}^{65 / 63}\right)$, was used to calculate the mass bias corrected ${ }^{65} \mathrm{Cu} /{ }^{63} \mathrm{Cu}$ isotope amount ratio in the sample $\left(R_{\text {sample' }}^{65 / 63}\right.$ Equation 4).

$$
\begin{gathered}
f^{\mathrm{Cu}}=\frac{\ln \left(\frac{R_{\text {HCU-1 }}^{65 / 63}}{r_{\text {HHCU-1 }}^{65 / 63}}\right)}{\ln \left(\frac{m_{65}}{m_{63}}\right)} \\
R_{\text {HICU-1 }}^{71 / 69}=r_{\text {HICU-1 }}^{71 / 69} \cdot\left(\frac{m_{71}}{m_{69}}\right)^{f C u} \\
f^{G a}=\frac{\ln \left(\frac{R_{\text {HIIU-1 }}^{71 / 69}}{r_{\text {sample }}}\right)}{\ln \left(\frac{m_{71}}{m_{69}}\right)} \\
R_{\text {sample }}^{65 / 63}=r_{\text {sample }}^{65 / 63} \cdot\left(\frac{m_{65}}{m_{63}}\right)^{f G a}
\end{gathered}
$$

The parts per thousand or permil (\%) variation in the mass bias corrected ${ }^{65} \mathrm{Cu} /{ }^{63} \mathrm{Cu}$ isotope amount ratios of the samples relative to the HICU- 1 standard are expressed in delta ( $\delta$ ) notation and were calculated using Equation 5) with a $R_{\text {HICU-1 }}^{65 / 63}$ value of 0.44561 . HICU- 1 was determined against NIST SRM $976 \mathrm{Cu}$ using C-SSBIN to correct for mass bias, and a $\delta^{65} \mathrm{Cu}$ value of $-0.04 \pm 0.03 \%$ o $(U, k=2)$ was determined (Table 6). All data were subsequently recalculated and reported relative to NIST SRM 976 (Equation 6).

$$
\begin{aligned}
& \delta^{65} \mathrm{CU}_{\text {samplevs. HICU-1 }}=\left(\frac{R_{\text {sample }}^{65 / 63}-1}{R_{\text {HICU-1 }}^{65 / 63}}\right) \\
& \delta^{65} \mathrm{Cu}_{\text {samplevs. SRM976 }}=\left[\left(\frac{\delta^{65} \mathrm{Cu}_{\text {samplevs. HICU-1 }}}{1000}+1\right) .\right. \\
& \left.\left(\frac{\delta^{65} \text { CUHICU-1 vs. SRM976 }_{\text {H. }}}{1000}+1\right)-1\right]
\end{aligned}
$$

It should be noted that the true isotope amount ratios of $\mathrm{Cu}$ in HICU-1 $\left(R_{\mathrm{HICU}-1}^{65 / 63}\right)$ and Ga in NIST SRM 994 are not required for this correction because the $\mathrm{Ga}$ internal standard element serves as an isotopic fractionation correction proxy (Yang et al. 2018). The value obtained for the Ga isotope amount ratio may be biased due to the limitations of the isotopic fractionation correction model (e.g., $f_{C u}=f_{G a}$ ), but this is mostly negated in the second step of the calibration from $\mathrm{Ga} \rightarrow \mathrm{Cu}$ (Yang et al. 2018). The main advantage of the CSSBIN as compared with SSB is that irregular changes in the instrumental isotopic fractionation during the measurement sequence are corrected for (Yang et al. 2018) since the internal standard is added to both the bracketing calibrator and sample, and is measured in both solutions. As a result, CSSBIN produces better measurement precision in general.

\section{Uncertainty estimation for $\delta^{65} \mathrm{Cu}$}

The combined uncertainty associated with the reported $\delta^{65} \mathrm{Cu}$ was estimated in accordance with JCGM 2008 'Guide to the Expression of Uncertainty in Measurement', using the following law of propagation of uncertainty:

$$
\begin{aligned}
u^{2}(y) & =\sum_{i=1}^{N}\left(\frac{\partial f}{\partial x_{i}}\right) \cdot u^{2}\left(x_{i}\right) \\
& +2 \cdot \sum_{i=1}^{N-1} \sum_{i=i+1}^{N}\left(\frac{\partial f}{\partial x_{i}}\right) \cdot\left(\frac{\partial f}{\partial x_{i}}\right) \cdot u\left(x_{i}, x_{i}\right)
\end{aligned}
$$

where $y=f\left(x_{1}, x_{2}, \ldots, x_{N}\right) . \partial f / \partial x_{i}$ are partial derivatives, $u\left(x_{i}\right)$ is the standard uncertainty associated with the input $x_{i}$, and $u$ $\left(x_{i}, x_{i}\right)$ is the estimated covariance associated with $x_{i}$ and $x_{i}$. For a simplicity, the Equation (8) can be used to calculate the uncertainty of $\delta^{65} \mathrm{Cu}$, since Equation (5) can be simplified to $\delta^{65} \mathrm{Cu}=r_{\text {sample }}^{65 / 63} / r_{\text {std }}^{65 / 63}-1$. Detailed information and an example of the calculation of $u\left(\delta^{65} \mathrm{Cu}\right)$ are provided in online supporting information Appendix S1.

$$
\begin{aligned}
u^{2}\left(\delta^{65} \mathrm{Cu}\right) & =\left(\frac{1}{r_{\text {std }}^{65 / 63}}\right)^{2} \cdot u^{2}\left(r_{\text {sample }}^{65 / 63}\right) \\
& +\left(-\frac{r_{\text {sample }}^{65 / 63}}{\left(r_{\text {std }}^{65 / 63}\right)^{2}}\right)^{2} \cdot u^{2}\left(r_{\text {std }}^{65 / 63}\right)
\end{aligned}
$$

\section{Copper isotopic analysis in the candidate isotopic reference material HICU-1}

The results of the $\mathrm{Cu}$ isotopic analysis of the twelve individual $\mathrm{Cu}$ wire pieces compared with the mixture of $\mathrm{Cu}$ solutions (HICU-1) are summarised in Table 4. Using SSB, a $\delta^{65} \mathrm{Cu}_{\text {HICU-1 }}$ value of $-0.02 \pm 0.17 \%$ o $(U, k=2)$ was determined, whereas with C-SSBIN, the $\delta^{65} \mathrm{Cu}_{\text {HICU-1 }}$ value was $-0.01 \pm 0.04 \%$ o $(U, k=2)$. It is evident that the uncertainty of measurements was improved $\sim$ fourfold using C-SSBIN compared with SSB alone, demonstrating its superiority. The $\delta^{65} \mathrm{Cu}_{\text {HICU-1 }}$ value of the $\mathrm{Cu}$ wire pieces is within the uncertainty of measurements of the candidate HICU-1 reference material, demonstrating sufficient 


\section{GEOSTANDARDS and GEOANALYTICAL}

Table 4.

Results of $\mathrm{Cu}$ wire homogeneity test

\begin{tabular}{|c|c|c|c|}
\hline Material & $n$ & 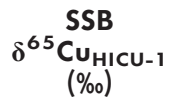 & $\begin{array}{c}\text { C-SSBIN } \\
\delta^{65} \mathrm{Cu}_{\text {HICU-1 }} \\
(\% 0)\end{array}$ \\
\hline Cu-1 & 5 & $-0.01 \pm 0.10$ & $-0.01 \pm 0.01$ \\
\hline Cu-2 & 5 & $-0.01 \pm 0.05$ & $-0.01 \pm 0.01$ \\
\hline Cu-3 & 5 & $0.01 \pm 0.06$ & $-0.01 \pm 0.01$ \\
\hline Cu-4 & 5 & $0.01 \pm 0.04$ & $-0.01 \pm 0.01$ \\
\hline Cu-5 & 5 & $0.01 \pm 0.09$ & $0.00 \pm 0.00$ \\
\hline Cu-6 & 5 & $0.02 \pm 0.14$ & $-0.01 \pm 0.01$ \\
\hline Cu-7 & 5 & $-0.01 \pm 0.03$ & $-0.01 \pm 0.01$ \\
\hline Cu-8 & 5 & $-0.02 \pm 0.03$ & $-0.01 \pm 0.01$ \\
\hline Cu-9 & 5 & $-0.16 \pm 0.22$ & $-0.01 \pm 0.01$ \\
\hline Cu-10 & 5 & $-0.10 \pm 0.06$ & $-0.01 \pm 0.01$ \\
\hline Cu-11 & 5 & $0.06 \pm 0.26$ & $-0.02 \pm 0.02$ \\
\hline Cu-12 & 5 & $-0.02 \pm 0.29$ & $-0.01 \pm 0.01$ \\
\hline Mean & & -0.02 & -0.01 \\
\hline $2 s$ & & 0.12 & 0.01 \\
\hline$U, k=2$ & & 0.17 & 0.04 \\
\hline
\end{tabular}

$n=$ total number of $\mathrm{Cu}$ isotope ratio measurements performed on each dissolved pure $\mathrm{Cu}$ wire piece by MC-ICP-MS.

homogeneity and the suitability of this material as a $\mathrm{Cu}$ isotopic reference material.

Subsequent experiments were performed, and a $\delta^{65} \mathrm{Cu}$ value of $-0.25 \pm 0.05 \%$ o $(U, k=2)$ was obtained in HICU-1 relative to $\mathrm{ERM}^{\circledR}$-AE647, whereas a $\delta^{65} \mathrm{Cu}$ value of $-0.04 \pm 0.03 \%$ o $(U, k=2)$ was found in $\mathrm{HICU}-1$ relative to NIST SRM976. As stated in the ERM ${ }^{\circledR}$-AE647 certificate (2013), its Cu isotope amount ratio was calibrated with NIST SRM 976, and Moeller et al. (2012) reported a value of $-0.21 \pm 0.05 \%$ o $(U, k=2)$ for NIST SRM 976 relative to the ERM ${ }^{\circledR}$-AE647; however, this is in disagreement with the mean $\delta^{65} \mathrm{Cu}$ value $((0.44563 / 0.44560-1) \times 1000=0.067 \%)$ calculated from the certified values in NIST SRM 976 $\left(R_{65 / 63}=1 / R_{63 / 65}=1 / 2.2440=0.44563\right.$, NIST Cu certificate 1994) and ERM ${ }^{\circledR}-\mathrm{AE6} 47\left(R_{65 / 63}=0.44560\right.$, IRMM Cu certificate, 2013), respectively. Thus in this study, NIST SRM 976 was measured against ERM ${ }^{\circledR}-A E 647$, and a $\delta^{65} \mathrm{Cu}$ value of $-0.21 \pm 0.06 \%(U, k=2)$ was obtained, in excellent agreement with the result reported by Moeller et al. (2012).

\section{Monitoring of in-house standards and reference material matrix doped with HICU-1}

Synthetic serum standards doped with HICU-l and a HICU-1 single-element standard were processed alongside samples through the entire anion exchange column chromatography procedure to monitor the efficacy of the separation method. The synthetic serum standards and single-element standard were prepared with HICU-1, meaning that when measured against the HICU-1 bracketing calibrator during C-SSBIN, they should return $\delta^{65} \mathrm{Cu}_{\text {HICU-1 }}$ values of $0 \%$, with any variation being accounted for by measurement uncertainty. The results of this monitoring returned $\delta^{65} \mathrm{CU}_{\text {HICU-1 }}$ values of synthetic serum standards and pure HICU-1 from - $0.02 \pm 0.08 \%$ $(U, k=2)$ to $0.00 \pm 0.05 \%$ o $(U, k=2)$ throughout the study period (Table 5). As a further means of validating results, elements removed in the first $3 \mathrm{ml}$ of the chromatography procedure (Figure 1) were collected from several reference materials after both the first and the second passes through columns and combined. This matrix solution contained all elements except $\mathrm{Cu}$, which was eluted in the subsequent $15 \mathrm{ml}$ of $7.6 \mathrm{~mol} \mathrm{I}^{-1} \mathrm{HCl}$, and $\mathrm{Fe}$ and $\mathrm{Zn}$, which remained on the column throughout $\mathrm{Cu}$ elution. This Cu-free solution of matrix elements was then doped with $\mathrm{HICU}-1$ to replace sample Cu with the same mass of $\mathrm{Cu}$ that would have been in the original processed aliquot of sample and then dried down and processed through the entire two-pass chromatography procedure before isotopic analysis. As with the synthetic serum standards and pure HICU-1 standard, reference material matrix doped with $\mathrm{HICU}_{-1}$ should produce $\delta^{65} \mathrm{Cu}_{\mathrm{HICU}-1}$ values of $0 \%$ within uncertainty of measurements. If any original $\mathrm{Cu}$ or matrix/interference elements remain after reprocessing, they would impart a portion of the $\delta^{65} \mathrm{Cu}$ value from the original sample on HICU-1 and cause matrix/interference effects, respectively. DOLT-5, DORM-4, TORT-3 and BIR-1 underwent this novel validation method, and despite the differences in the matrices and original $\delta^{65} \mathrm{Cu}$ values, $\delta^{65} \mathrm{Cu}_{\mathrm{HICU}_{-1}}$ values of

Table 5.

Synthetic standards and reference materials matrix doped with HICU-1 (mean, $U, k=2$ )

\begin{tabular}{|c|c|c|}
\hline Material & $\mathrm{n}(I)$ & $\begin{array}{c}\delta^{65} \mathrm{CU}_{\text {HICU-1 }}(\%) \\
\text { [Doped with } \\
\text { HICU-1] }\end{array}$ \\
\hline $\begin{array}{l}\text { Low Cu synthetic serum } \\
(0.6 \mu \mathrm{g} \mathrm{Cu})\end{array}$ & $19(7)$ & $-0.02 \pm 0.08(0.05)^{a}$ \\
\hline $\begin{array}{l}\text { High Cu synthetic serum } \\
(9.9 \mu \mathrm{g} \mathrm{Cu})\end{array}$ & $13(4)$ & $-0.02 \pm 0.07(0.06)$ \\
\hline HICU-1 $(10 \mu \mathrm{g} \mathrm{Cu})$ & $11(3)$ & $0.00 \pm 0.05(0.03)$ \\
\hline $\begin{array}{l}\text { DOLT-5 Cu-doped } \\
\text { matrix }(3.1 \mu \mathrm{g} \mathrm{Cu})\end{array}$ & $8(3)$ & $-0.01 \pm 0.03(0.02)$ \\
\hline $\begin{array}{l}\text { DORM-4 Cu-doped } \\
\text { matrix }(1.6 \mu \mathrm{g} \mathrm{Cu})\end{array}$ & 9 (3) & $0.02 \pm 0.06(0.04)$ \\
\hline $\begin{array}{l}\text { TORT-3 Cu-doped } \\
\text { matrix }(30.9 \mu \mathrm{g} \mathrm{Cu})\end{array}$ & $3(1)$ & $0.02 \pm 0.05(0.03)$ \\
\hline $\begin{array}{l}\text { BIR-1 Cu-doped matrix } \\
(3.0 \mu \mathrm{g} \mathrm{Cu})\end{array}$ & $3(1)$ & $-0.02 \pm 0.06(0.04)$ \\
\hline
\end{tabular}

$\mathrm{I}$ = number of reference material aliquots digested and processed through chromatography procedure, $n=$ total number of $\mathrm{Cu}$ isotope ratio measurements performed on each material by MC-ICP-MS.

$\left.{ }^{a}\right)$ values in parenthesis are $2 s$. 
Table 6.

Results (mean, $U, k=2$ ) for reference materials

\begin{tabular}{|c|c|c|c|c|c|c|c|}
\hline Material & Type & $\begin{array}{c}C u \\
\left(\mu \mathbf{g ~ g}^{-1}\right)\end{array}$ & $n(I)$ & $\delta^{65} \mathrm{Cu}_{\text {HICU-1 }}(\%)$ & $\delta^{65} C_{\text {SRM } 976}(\% 0)$ & Reported $^{a}$ & Source \\
\hline HICU-1 & Copper wire & & 18 & & $-0.04 \pm 0.03(0.02)^{c}$ & & \\
\hline DOLT-5 & Dogfish liver & 35 & $23(6)$ & $0.02 \pm 0.07(0.04)^{c}$ & $-0.02 \pm 0.08(0.04)$ & & \\
\hline DORM-4 & Fish protein & 15.7 & $17(6)$ & $0.57 \pm 0.07(0.05)$ & $0.52 \pm 0.08(0.05)$ & & \\
\hline TORT-3 & $\begin{array}{l}\text { Lobster } \\
\text { hepatopancreas }\end{array}$ & 497 & $18(6)$ & $0.41 \pm 0.04(0.03)$ & $0.36 \pm 0.05(0.03)$ & & \\
\hline MESS-4 & Marine sediment & 32.9 & $21(6)$ & $-0.05 \pm 0.06(0.04)$ & $-0.09 \pm 0.07(0.04)$ & & \\
\hline PACS 3 & Marine sediment & 326 & $15(5)$ & $-0.05 \pm 0.08(0.05)$ & $-0.10 \pm 0.09(0.05)$ & & \\
\hline BHVO-1 & Hawaiian basalt & 136 & 9 (3) & $0.04 \pm 0.07(0.05)$ & $-0.01 \pm 0.08(0.05)$ & $-0.23 \pm 0.14(n=3)$ & Makishima (2014) \\
\hline BIR-1 & Icelandic basalt & 120 & $9(3)$ & $0.04 \pm 0.07(0.04)$ & $-0.01 \pm 0.08(0.04)$ & $\begin{aligned}-0.01 & \pm 0.04(n=5)^{*} \\
-0.02 & \pm 0.10(n=31) \\
0.00 & \pm 0.03(n=2) \\
0.08 & \pm 0.07(n=6)\end{aligned}$ & $\begin{array}{l}\text { Liu et al. (2014) } \\
\text { Li et al. (2009) } \\
\text { Sossi et al. (2015) } \\
\text { Moeller et al. (2012) }\end{array}$ \\
\hline W-2a & Diabase & 110 & $11(3)$ & $0.09 \pm 0.08(0.06)$ & $0.04 \pm 0.09(0.06)$ & $0.11 \pm 0.02(m=2)^{*}$ & Liv et al. (2014) \\
\hline SGR-1b & Green River Shale & 53.3 & $11(3)$ & $0.34 \pm 0.08(0.06)$ & $0.29 \pm 0.09(0.06)$ & & \\
\hline Seronorm ${ }^{b}$ & Human serum & 1.2 & $5(2)$ & $-0.15 \pm 0.05(0.03)$ & $-0.20 \pm 0.06(0.03)$ & $\begin{array}{l}-0.20 \pm 0.04(m=3)^{*} \\
-0.19 \pm 0.05(m=4)^{*} \\
-0.24 \pm 0.14(m=4)^{*} \\
-0.07 \pm 0.07(m=2)^{*}\end{array}$ & $\begin{array}{l}\text { Lauwens et al. (2018) } \\
\text { Lauwens et al. (2017) } \\
\text { Lauwens et al. (2016) } \\
\text { Costas-Rodriguez et al. } \\
(2015)\end{array}$ \\
\hline
\end{tabular}

a The previously reported Cu isotopic compositions were calculated relative to NIST SRM 976 (mean, 2s).

b Seronorm ${ }^{T M}$ Trace Elements Serum L-1, I = number of reference material aliquots digested and passed through column chemistry, $n=$ total number of $\mathrm{Cu}$ isotope ratio measurements performed on each reference material by MC-ICP-MS.

c 0 values in parenthesis are $2 s^{*}$ mean $\delta^{65} \mathrm{Cu} \pm 2 s$ of mean after $m$ isolation and measurement sessions.

$-0.02 \pm 0.08 \%(U, k=2)$ to $0.02 \pm 0.06 \%$ o $(U, k=2)$ (Table 5) were measured. For example, DORM-4 has a $\delta^{65} \mathrm{Cu}_{\text {HICU-1 }}$ value of $0.57 \pm 0.07 \%$ o $(U, k=2$ in Table 6$)$, but DORM-4 matrix doped with HICU-1 Cu and reprocessed through the chromatography procedure produced a $\delta^{65} \mathrm{Cu}_{\text {HICU-1 }}$ value of $0.02 \pm 0.06 \%$ o $(U, k=2$ in Table 5). These results further confirm that the proposed method is accurate within measurement uncertainties reported.

\section{$\mathrm{Cu}$ isotope amount ratio measurements of reference materials}

The reference materials measured in this study possess complex and varied matrices with Cu mass fractions ranging from $1.2 \mu \mathrm{g} \mathrm{g}^{-1}$ to $497 \mu \mathrm{g} \mathrm{g}^{-1}$, and the $\delta^{65} \mathrm{CU}_{\text {SRM976 }}$ values range from $-0.20 \%$ to $0.52 \%$ (Figure 2, Table 6), covering much of the natural $\mathrm{Cu}$ isotope variability observed in the environment.

DOLT-5, DORM-4 and TORT-3 are intended for use in the calibration of procedures and the development of methods for the determination of trace and matrix constituents in marine fauna and materials of similar matrix. For the first time, these materials were analysed for the $\delta^{65} \mathrm{Cu}$. The Cu isotopic homogeneity of two separate bottles for each material was examined with three $0.25 \mathrm{~g}$ aliquots digested from each for a total of six aliquots analysed from each material. These materials were found to possess

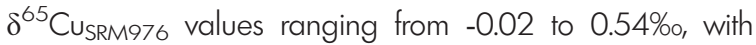
${ }^{65} \mathrm{Cu}$ enrichment increasing from DOLT-5 (dogfish liver) with

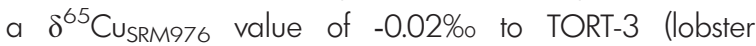
hepatopancreas) with a $\delta^{65} \mathrm{Cu}_{\text {SRM } 976}$ value of $0.36 \%$ to DORM-4 (fish protein) with a $\delta^{65} \mathrm{CU}_{\text {SRM976 value of } 0.52 \% \text {. }}$ Cadmium (Cd), Zinc ( $\mathrm{Zn}$ ) and lead (Pb) isotope amount ratios have been used to distinguish between natural and anthropogenic sources and fingerprint sources of metal contamination in bivalves off the coasts of France, Western Canada and the United States (Shiel et al. 2012, 2013). Copper abundances in bivalve mussels from the United States, Hong Kong, Canada, Turkey, Italy and Chile range from 1.4 to $744 \mu \mathrm{g} \mathrm{g}^{-1}$ (De Gregori et al. 1994), which is similar to the Cu mass fractions found in DOLT-5, DORM-4 and TORT-3, making them suitable candidates for being measured alongside bivalve mussels being analysed for $\delta^{65} \mathrm{Cu}$ values. The characterisation of these marine fauna reference materials with varying $\mathrm{Cu}$ abundances as isotopic standards may enable $\mathrm{Cu}$ isotopes to be used in conjunction with $\mathrm{Cd}, \mathrm{Zn}$ and $\mathrm{Pb}$ isotopes for the definitive fingerprinting of pollution sources and distinguishing of natural and anthropogenic metal sources.

Wilson's disease (WD) is an inherited Cu metabolism disorder that leads to excess $\mathrm{Cu}$ accumulation in the liver. The Cu mass fraction in liver biopsies is currently used as one 


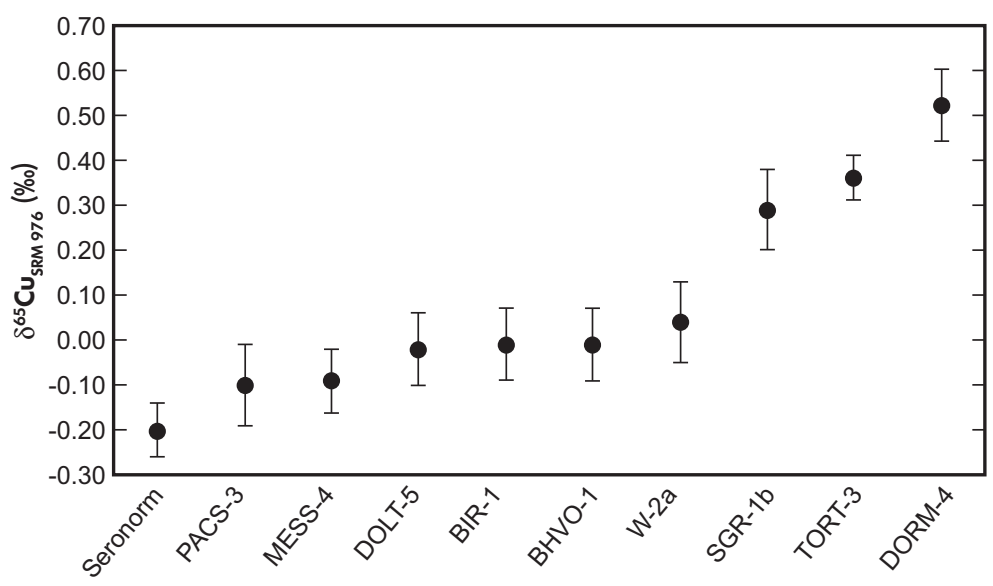

Figure 2. Visualisation of reference material $\delta^{65} \mathrm{Cu}$ values. Bars represent $U, k=2$ (see text for details).

of the parameters to diagnose WD, but a combination of clinical and biochemical tests is required to diagnose WD and exclude other diseases (Ferenci et al. 2005). A comprehensive study found liver biopsy Cu mass fractions in 'healthy', non-WD subjects ranged from $12.5 \mu \mathrm{g} \mathrm{g}^{-1}$ to $80.8 \mu \mathrm{g} \mathrm{g}^{-1}$ with a mean of $34.9 \mu \mathrm{g} \mathrm{g}^{-1}$, whereas patients with WD had liver Cu mass fractions that went as high as $5000 \mathrm{\mu g} \mathrm{g}^{-1}$ (Ferenci et al. 2005). Given the invasive nature of the surgery, gaining additional diagnostic information from liver biopsy samples should be a priority to justify the procedure. Copper mass fractions alone are insufficient for a WD diagnosis, but it is possible that a $\delta^{65} \mathrm{Cu}$ could complement this data by tracing the functional deficiency of Cu-transporting adenosinetriphosphatase, ATP7B, that is highly active in hepatocytes and leads to the gradual accumulation of $\mathrm{Cu}$ in the liver (Bull et al. 1993, Tanzi et al. 1993). The combination of Cu mass fraction and isotopic data may provide greater sensitivity and specificity in the diagnosis of WD, and the validity of these measurements could be ensured through the analysis of high Cu DOLT-5 and TORT-3 alongside liver biopsy samples.

MESS-4 and PACS-3 are primarily intended for use in the calibration of procedures and development of methods for the determination of trace and matrix constituents in marine sediments and materials with similar matrices. For the first time, we have determined the $\delta^{65} \mathrm{Cu}$ of NRC marine sediment certified reference materials MESS- 4 and PACS-3. Two bottles of each material were used in this study, and three $0.25 \mathrm{~g}$ aliquots (following the recommendation of the certification report) were digested from both MESS-4 bottles whereas three were digested from the first bottle of PACS-3 and two from the second. MESS-4 was found to have a $\delta^{65} \mathrm{Cu}_{\text {SRM976 value of }}-0.09 \pm 0.07 \%$ o $(U, k=2)$ whereas PACS-3 was found to have a $\delta^{65} \mathrm{Cu}_{\text {SRM976 }}$ value of
$-0.10 \pm 0.09 \%$ o $(U, k=2)$. Older reference materials, MESS-3 and PACS-2, were analysed in a recent paper (Araújo et al. 2019) and found to possess slightly different $\delta^{65} \mathrm{Cu}_{\text {SRM976 values of } 0.03 \pm 0.10 \%}(2 s, n=9)$ and $0.05 \pm 0.06 \%$ o (2s, $n=3)$, respectively. This might be due to the difference in the production of reference materials in different time. It is interesting that both marine sediment reference materials were found to possess similar $\delta^{65} \mathrm{CU}_{\text {SRM976 }}$ despite MESS-4 being taken from the Beaufort Sea and PACS-3 being taken from the harbour Esquimalt off the southern tip of Vancouver Island in British Columbia, Canada. However, this is unsurprising given the similar origin of the island arcs that eventually became the accreted terranes that comprise the rocks of both British Columbia and Alaska and eroded to form these marine sediments.

The Hawaiian basalt reference material, BHVO-1, was selected because to our knowledge, its $\delta^{65} \mathrm{CU}_{\text {SRM976 value is }}$ reported in just one study (Makishima 2014). In that study, a $\delta^{65} \mathrm{Cu}_{\text {SRM976 value of }}-0.23 \pm 0.14 \%$ ( 2 s) was determined, which is approximately $0.33 \%$ lighter than that reported for the later BHVO-2 and the mean precision of the measurements of silicate reference materials during the study was $\pm 0.25 \%$ ( $1 s)$. We report a $\delta^{65} \mathrm{Cu}_{\text {SRM976 value of }}$ $-0.01 \pm 0.08 \%$ o $(U, k=2)$ in three separate digests of BHVO-1, bringing its $\delta^{65} \mathrm{Cu}_{\text {SRM976 }}$ more in-line with a weighted mean of results previously reported for BHVO-2 $\left(\delta^{65} \mathrm{Cu}_{\text {SRM976 }}=0.10 \%\right.$ o, $\left.n=49\right)$ (Moynier et al. 2010, Moeller et al. 2012, Liu et al. 2014, Sossi et al. 2015, Hou et al. 2016) and values typically observed in basalts. Despite the $\sim 0.10 \%$ difference between our measurements and the BHVO-2 weighted mean, Sossi et al. (2015) reported a

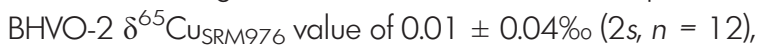
which is within the uncertainty of our measurements. 
The Icelandic basalt reference material, BIR-1, is commercially available and widely reported in $\mathrm{Cu}$ isotopic studies (Li et al. 2009, Moeller et al. 2012, Liu et al. 2014, Sossi et al. 2015). Here, we report a $\delta^{65} \mathrm{CU}_{\text {SRM976value of }}$ $-0.01 \pm 0.08 \%(U, k=2)$ in three separate digests of BIR-1, which is in agreement with the weighted mean BIR-1 $\delta^{65} \mathrm{Cu}_{\text {SRM976 }}$ value reported in past studies $(0.00 \%$, $n=44$ ). The agreement between our BIR-1 results and past published results supports the validity of the results reported in this study for BHVO-1 due to their highly similar matrix and geologic origin. The diabase, $\mathrm{W}-2 \mathrm{a}$, is commercially available and has been reported in one past study published by Liu et al. (2014). Here, we report a $\delta^{65} \mathrm{CU}_{\text {SRM976 value of }} 0.04 \pm 0.09 \%(U, k=2)$ in three separate digests of $\mathrm{W}-2 \mathrm{a}$, which is within the uncertainty of the reported W-2a $\delta^{65} \mathrm{Cu}_{\text {SRM976 value }}(0.11 \%, n=12)$.

For the first time, we report a $\delta^{65} \mathrm{CU}_{\text {SRM976 value for the }}$ Green River shale reference material, SGR-1b, of $0.29 \pm 0.09 \%$ o $(U, k=2)$. To our knowledge, this is the first report of $\delta^{65} \mathrm{Cu}$ values for a commercially available shale reference material, and its measurement will provide researchers investigating redox processes and metallic cycling in shales with a matrix-matched RM to support the accuracy and validity of their measurements. Of a sampling of four studies that investigated $\mathrm{Cu}$ isotopic fractionation in shales (Asael et al. 2007, Mathur et al. 2012, Chi Fru et al. 2016, Lv et al. 2016), just one reported the measurement of Cu reference materials alongside their samples (Lv et al. 2016). However, these reference materials are igneous rocks, which possess a different matrix from shales. Basalts and other igneous rocks tend to contain greater mass fractions of most elements, including $\mathrm{Na}, \mathrm{Ti}, \mathrm{Ca}$ and $\mathrm{Fe}$, but SGR-1 $\mathrm{b}$ contains over 3 and 66 times more $\mathrm{K}$ than BHVO- 1 and BIR-1, respectively, which chromatography procedures may not be calibrated to completely remove from samples, potentially causing matrix effects.

Seronorm ${ }^{\mathrm{TM}}$ Trace Elements Serum L-1 has been measured for $\delta^{65} \mathrm{Cu}$ in four previous studies (Costas-Rodríguez et al. 2015, Lauwens et al. 2016, 2017, Lauwens et al. 2018), and bottles with at least three different lot numbers were used (unreported in Costas-Rodriguez et al. (2015)). A weighted mean $\delta^{65} \mathrm{Cu}_{\text {SRM976 value of }}-0.19 \pm 0.05 \%$ o ( $2 \mathrm{~s}$, $n=33$ ) was obtained in the two most recent publications using Seronorm ${ }^{T M}$ as a reference material (Lauwens et al. 2017, Lauwens et al. 2018). A study published the year before (Lauwens et al. 2016) reported a $\delta^{65} \mathrm{CU}_{\text {SRM976 value }}$ of $-0.24 \pm 0.14 \%$ o $(2 s)$, which is also within the uncertainty. However, the measurements performed by Costas-Rodriguez et al. (2015) are outliers with reported $\delta^{65} \mathrm{CU}_{\text {SRM976 }}$ values of $-0.09 \pm 0.05 \%$ o (2s) and $-0.04 \pm 0.05 \%$ o (2s) over an unknown number of measurements on a bottle of undeclared lot number. Our result of $-0.20 \pm 0.06 \%$ $(U, k=2)$ is in agreement with those reported in the three Lauwens et al. studies but additional bottles of different lot numbers should be analysed by different research groups to determine its suitability as the first serum $\mathrm{Cu}$ isotopic reference material.

\section{Conclusions}

The robust characterisation of $\delta^{65} \mathrm{Cu}$ values in a wide variety of geological and biological reference materials is a crucial step in the effort to study the processes that govern $\mathrm{Cu}$ distribution in new media and environments. Six reference materials comprising DOLT-5 (dogfish liver), DORM-4 (fish protein), TORT-3 (lobster hepatopancreas), MESS-4 (marine sediment), PACS-3 (marine sediment) and SGR-1b (Green River shale) have for the first time been characterised for $\delta^{65} \mathrm{Cu}$. Additionally, four reference materials with published $\delta^{65} \mathrm{Cu}$ values have been measured, comprising BHVO-1 (Hawaiian basalt), BIR-1 (Icelandic basalt), W-2a (diabase) and Seronorm ${ }^{T M}$ Trace Elements Serum L-1 (human serum).

The determination of $\delta^{65} \mathrm{Cu}$ values was achieved using the C-SSBIN mass bias correction model with $\mathrm{Ga}$ as an internal standard after Hou et al. (2016) and validated by (a) monitoring $\mathrm{Ti} / \mathrm{Cu}$ and $\mathrm{Na} / \mathrm{Cu}$ ratios of column-processed materials to ensure contaminant levels remained negligible, (b) determining $\mathrm{Cu}$ yield and separation quality using quantitative and semi-quantitative methods, (c) consistently achieving procedural blank $\mathrm{Cu}$ contributions that were negligible $(<0.5 \%)$ relative to the amount of $\mathrm{Cu}$ processed in all study materials, (d) preparing and processing two synthetic standards doped with HICU-1 $\mathrm{Cu}$ through the chromatography procedure and consistently producing $\delta^{65} \mathrm{Cu}$ values of $0 \%$ relative to bracketing calibrator HICU-1, (e) doping matrix elements collected during $\mathrm{Cu}$ chromatography with $\mathrm{HICU}-1 \mathrm{Cu}$ and reprocessing doped materials through the chromatography procedure to verity that $\delta^{65} \mathrm{Cu}$ values of $0 \%$ were produced when bracketed with $\mathrm{HICU}-1$ and $(f)$ measuring similar $\delta^{65} \mathrm{Cu}$ values in previously characterised reference materials using our methodologies. We recommend the reference materials characterised by this study to be analysed alongside samples with similar matrices in future $\mathrm{Cu}$ isotopic studies and expect them to help researchers investigating biological processes in marine fauna, high Cu tissues and serum, high temperature geological processes in igneous rocks, anthropogenic processes in marine sediments, and redox processes and metallic cycling in shale. 


\section{GEOSTANDARDS and \\ GEOANALYTICAL}

\section{Acknowledgements}

We thank Dr. Robert D. Vocke, Jr. from the National Institute of Standards and Technology (Gaithersburg, MD, USA) for the courtesy of NIST SRM 976 isotopic standard of copper. We would like to thank the Kimberley Foundation for their generous financial support with the Hugh C. Morris Experiential Learning Fellowship, without which this project would not have been possible. Special thanks also go to Juan He and Kenny Nadeau (NRC, Ottawa Canada) for their help regarding instrumentation and troubleshooting.

\section{Conflict of interest}

The authors declare no competing financial interests to influence the work reported in this paper.

\section{Data availability statement}

Data available on request due to privacy/ethical restrictions.

\section{References}

Albarède F., Télouk P., Lamboux A., Jaouen $\mathrm{K}$. and Balter V. (2011)

Isotopic evidence of unaccounted for Fe and $\mathrm{Cu}$ erythropoietic pathways. Metallomics, 3, 926-933.

Albarède F., Télouk P. and Balter V. (2017) Medical applications of isotope metallomics. Reviews in Mineralogy and Geochemistry, 82, 851-885.

Aramendía M., Rello L., Resano M. and Vanhaecke F. (2013)

Isotopic analysis of $\mathrm{Cu}$ in serum samples for diagnosis of Wilson's disease: a pilot study. Journal of Analytical Atomic Spectrometry, 28, 675-681.

Araújo D.F., Ponzevera E., Briant N., Knoery J., Bruzac S., Sireau T. and Brach-Papa C. (2019)

Copper, zinc and lead isotope signatures of sediments from a Mediterranean coastal bay impacted by naval activities and urban sources. Applied Geochemistry, 111 , 104440.

Asael D., Matthews A., Bar-Matthews M. and Halicz L. (2007)

Copper isotope fractionation in sedimentary copper mineralization (Timna Valley, Israel). Chemical Geology, 243, 238-254.

Baconnais I., Rouxel O., Dulaquais G. and Boye M. (2019)

Determination of the copper isotope composition of seawater revisited: A case study from the Mediterranean Sea. Chemical Geology, 51 1, 465-480.
Balter V., Costa A.N., da Bondanese V.P., Jaouen K., Lamboux A., Sangrajrang S., Vincent N., Fourel F., Télouk P., Gigou M., Lécuyer C., Srivatanakul P., Bréchot C., Albarède F. and Hainaut P. (2015)

Natural variations of copper and sulfur stable isotopes in blood of hepatocellular carcinoma patients. Proceedings of the National Academy of Sciences of the United States of America, 1 12, 982-985.

Bermin J., Vance D., Archer C. and Statham P.J. (2006) The determination of the isotopic composition of $\mathrm{Cu}$ and $\mathrm{Zn}$ in seawater. Chemical Geology, 226, 280-297.

Borrok D.M., Wanty R.B., Ridley W.I., Wolf R., Lamothe P.J. and Adams M. (2007)

Separation of copper, iron, and zinc from complex aqueous solutions for isotopic measurement. Chemical Geology, 242, 400-414.

Bull P.C., Thomas G.R., Rommens J.M., Forbes J.R. and Cox D.W. (1993)

The Wilson disease gene is a putative copper transporting P-type ATPase similar to the Menkes gene. Nature Genetics, 5, 327.

Cadiou J.L., Pichat S., Bondanese V.P., Soulard A., Fujii T., Albarède F. and Oger P. (2017)

Copper transporters are responsible for copper isotopic fractionation in eukaryotic cells. Scientific Reports, 7, 44533

Chi Fru E., Rodríguez N.P., Partin C.A., Lalonde S.V., Andersson P., Weiss D.J., El Albani A., Rodushkin I. and Konhauser K.O. (2016)

$\mathrm{Cu}$ isotopes in marine black shales record the Great Oxidation Event. Proceedings of the National Academy of Sciences of the United States of America, 113, 49414946.

Costas-Rodríguez M., Anoshkina Y., Lauwens S., Vlierberghe H.V., Delanghe J. and Vanhaecke F. (2015) Isotopic analysis of $\mathrm{Cu}$ in blood serum by multi-collector ICP-mass spectrometry: A new approach for the diagnosis and prognosis of liver cirrhosis? Metallomics, 7, 491-498.

De Gregori l., Delgado D., Pinochet H., Gras N., Muñoz L., Bruhn C. and Navarrete G. (1994)

Cadmium, lead, copper and mercury levels in fresh and canned bivalve mussels Tagelus dombeii (Navajuela) and Semelle sólida (Almeja) from the Chilean coast. Science of the Total Environment, 148, 1-10

Ehrlich S., Butler I., Halicz L., Rickard D., Oldroyd A. and Matthews A. (2004)

Experimental study of the copper isotope fractionation between aqueous $\mathrm{Cu}(I I)$ and covellite, CuS. Chemical Geology, 209, 259-269. 
references

Ferenci P., Steindl-Munda P., Vogel W., Jessner W., Gschwantler M., Stauber R., Datz C., Hackl F., Wrba F. and Baver P. (2005)

Diagnostic value of quantitative hepatic copper determination in patients with Wilson's disease. Clinical Gastroenterology and Hepatology, 3, 81 1-818.

Flórez M.R., Costas-Rodńguez M., Grootaert C., Van Camp J. and Vanhaecke F. (2018)

$\mathrm{Cu}$ isotope fractionation response to oxidative stress in a hepatic cell line studied using multi-collector ICP-mass spectrometry. Analytical and Bioanalytical Chemistry, 410, 2385-2394.

Gale N.H., Woodhead A.P., Stos-Gale Z.A., Walder A. and Bowen I. (1999)

Natural variations detected in the isotopic composition of copper: Possible applications to archaeology and geochemistry. International Journal of Mass Spectrometry, 184, 1-9.

Gillson G.R., Douglas D.J., Fulford J.E., Halligan K.W. and Tanner S.D. (1988)

Nonspectroscopic interelement interferences in inductively coupled plasma-mass spectrometry. Analytical Chemistry, $60,1472-1474$.

Harrington J.M., Young D.J., Essader A.S., Sumner S.J. and Levine K.E. (2014)

Analysis of human serum and whole blood for mineral content by ICP-MS and ICP-OES: Development of a mineralomics method. Biological Trace Element Research, 160, 132-142.

Heumann K.G., Gallus S.M., Rädlinger G. and Vogl J. (1998)

Precision and accuracy in isotope ratio measurements by plasma source-mass spectrometry. Journal of Analytical Atomic Spectrometry, 13, 1001-1008.

Hou Q., Zhou L., Gao S., Zhang T., Feng L. and Yang L. (2016)

Use of Ga for mass bias correction for the accurate determination of copper isotope ratio in the NIST SRM

$3114 \mathrm{Cu}$ standard and geological samples by MC-ICPMS. Journal of Analytical Atomic Spectrometry, 31, 280-287.

\section{IRMM (2013)}

Certificate of analysis ERM®-AE647. IRMM (Geel). https:// crm.jrcec.europa.eu/p/40454/40476/By-application-fie Id/Stable-isotopes/ERM-AE647-COPPER-NATURAL-SPIKENITRATE-SOLUTION/ERM-AE647.

\section{Jaouen K. and Balter V. (2014)}

Menopause effect on blood $\mathrm{Fe}$ and $\mathrm{Cu}$ isotope compositions: Menopause effect on blood Fe and $\mathrm{Cu}$ isotopes. American Journal of Physical Anthropology, 153, 280285.

Jaouen K., Balter V., Herrscher E., Lamboux A., Telouk P. and Albarède F. (2012)

$\mathrm{Fe}$ and $\mathrm{Cu}$ stable isotopes in archeological human bones and their relationship to sex. American Journal of Physical Anthropology, 148, 334-340.
Jaouen K., Gibert M., Lamboux A., Telouk P., Fourel F., Albarède F., Alekseev A.N., Crubézy E. and Balter V. (2013)

Is aging recorded in blood $\mathrm{Cu}$ and $\mathrm{Zn}$ isotope compositions? Metallomics, 5, 1016-1024.

Jaouen K., Herrscher E. and Balter V. (2017)

Copper and zinc isotope ratios in human bone and enamel. American Journal of Physical Anthropology, 162, 491-500.

\section{JCGM 100 (2008)}

Evaluation of measurement data - Guide to the expression of uncertainty in measurement. International Organization for Standardization (Geneva), 134pp.

Kim B.-E., Nevitt T. and Thiele D.J. (2008)

Mechanisms for copper acquisition, distribution and regulation. Nature Chemical Biology, 4, 176-185.

Lauwens S., Costas-Rodríguez M., Vlierberghe H.V. and Vanhaecke F. (2016)

$\mathrm{Cu}$ isotopic signature in blood serum of liver transplant patients: A follow-up study. Scientific Reports, 6, 30683.

Lauwens S., Costas-Rodríguez M., Van Vlierberghe H. and Vanhaecke F. (2017)

High-precision isotopic analysis of $\mathrm{Cu}$ in blood serum via multi-collector ICP-mass spectrometry for clinical investigation: Steps towards improved robustness and higher sample throughput. Journal of Analytical Atomic Spectrometry, 32, 597-608.

Lauwens S., Costas-Rodríguez M., Delanghe J., Van Vlierberghe H. and Vanhaecke F. (2018)

Quantification and isotopic analysis of bulk and of exchangeable and ultrafiltrable serum copper in healthy and alcoholic cirrhosis subjects. Talanta, 189, 332-338.

Lauwens S., Costas-Rodríguez M. and Vanhaecke F. (2018)

Ultra-trace $\mathrm{Cu}$ isotope ratio measurements via multicollector ICP-mass spectrometry using Ga as internal standard: An approach applicable to micro-samples. Analytica Chimica Acta, 1025, 69-79.

Li W., Jackson S.E., Pearson N.J., Alard O. and Chappell B.W. (2009)

The Cu isotopic signature of granites from the Lachlan Fold Belt, SE Australia. Chemical Geology, 258, 38-49.

Linder M.C. and Goode C.A. (1991)

Biochemistry of copper. Springer-Verlag (New, York, NY), $413 p p$.

Little S.H., Vance D., Walker-Brown C. and Landing W.M. (2014)

The oceanic mass balance of copper and zinc isotopes, investigated by analysis of their inputs, and outputs to ferromanganese oxide sediments. Geochimica et Cosmochimica Acta, 21, 673-693.

Liu S.-A., Li D., Li S., Teng F., Ke S., He Y. and Lu Y. (2014) High-precision copper and iron isotope analysis of igneous rock standards by MC-ICP-MS. Journal of Analytical Atomic Spectrometry, 29, 122-133. 


\section{GEOSTANDARDS and \\ GEOANALYTICAL \\ RESEARCH}

references

Liu S.-A., Huang J., Liu J., Wörner G., Yang W., Tang Y.-J., Chen Y., Tang L., Zheng J. and Li S. (2015)

Copper isotopic composition of the silicate Earth. Earth and Planetary Science Letters, 427, 95-103.

Lv Y., Liu S.-A., Zhu J.-M. and Li S. (2016)

Copper and zinc isotope fractionation during deposition and weathering of highly metalliferous black shales in central China. Chemical Geology, 445, 24-35.

Machlan L.A., Gramlich J.W., Powell LJ. and Lambert G.M. (1986)

Absolute isotopic abundance ratio and atomic weight of a reference sample of gallium. Journal of Research of the National Bureau of Standards, 91, 323.

Makishima A. (2014)

Cu purification using an extraction resin for determination of isotope ratios by multicollector ICP-MS. Chromatography, 1, 96-107.

Maréchal C.N., Télouk P. and Albarède F. (1999)

Precise analysis of copper and zinc isotopic compositions by plasma-source mass spectrometry. Chemical Geology, 156, 251-273.

Mathur R., Jin L., Prush V., Paul J., Ebersole C., Fornadel A., Williams J.Z. and Brantley S. (2012)

$\mathrm{Cu}$ isotopes and concentrations during weathering of black shale of the Marcellus Formation, Huntingdon County, Pennsylvania (USA). Chemical Geology, 304, 175-184.

Mathur R., Munk L., Nguyen M., Gregory M., Annell H. and Lang J. (2013)

Modern and paleofluid pathways revealed by $\mathrm{Cu}$ isotope compositions in surface waters and ores of the Pebble Porphyry Cu-Au-Mo deposit, Alaska. Economic Geology, 108, 529-541.

Mathur R., Munk L., Roskowski J., Song S., Guo K., Tornos F., Titley S. and Reich M. (2014)

Consistent copper isotope footprints in surface and groundwater from multiple deposit types. Society of Economic Geologists Conference, 2014.

Miller K.A., Vicentini F.A., Hirota S.A., Sharkey K.A. and Wieser M.E. (2019)

Antibiotic treatment affects the expression levels of copper transporters and the isotopic composition of copper in the colon of mice. Proceedings of the National Academy of Sciences USA, 116, 5955-5960.

Milne D.B. (1998)

Copper intake and assessment of copper status. The American Journal of Clinical Nutrition, 67, 1041S-1045S.

Moeller K., Schoenberg R., Pedersen R.-B., Weiss D. and Dong S. (2012)

Calibration of the new certified reference materials ERMAE633 and ERM-AE647 for copper and IRMM-3702 for zinc isotope amount ratio determinations. Geostandards and Geoanalytical Research, 36, 177-199.
Moynier F., Koeberl C., Beck P., Jourdan F. and Télouk P. (2010)

Isotopic fractionation of $\mathrm{Cu}$ in tektites. Geochimica et Cosmochimica Acta, 74, 799-807.

Moynier F., Vance D., Fujii T. and Savage P. (2017)

The isotope geochemistry of zinc and copper. Reviews in Mineralogy and Geochemistry, 82, 543-600.

Moynier F., Creech J., Dallas J. and Le Borgne M. (2019)

Serum and brain natural copper stable isotopes in a mouse model of Alzheimer's disease. Scientific Reports, 9, $1-7$.

NIST (1986)

Certificate of analysis, Standard Reference Material 994 isotopic standard for gallium. National Institute of Standards and Technology (Gaithersburg, USA). https:// wmws.nist.gov/srmors/view_cert.cfm?srm=994.

NIST (1994)

Certificate of analysis, Standard Reference Material 976, isotopic standard for copper. National Institute of Standards and Technology (Gaithersburg, USA). https://wnws.nist.gov/srmors/view_detail.cfm?srm=976.

Sauzéat L, Bernard E., Perret-Liaudet A., Quadrio I., Vighetto A., Krolak-Salmon P., Broussolle E., Leblanc P. and Balter V. (2018)

Isotopic evidence for disrupted copper metabolism in amyotrophic lateral sclerosis. Science, 6, 264-271.

Shiel A.E., Weis D. and Orians K.J. (2012)

Tracing cadmium, zinc and lead sources in bivalves from the coasts of western Canada and the USA using isotopes. Geochimica et Cosmochimica Acta, 76, 175-190.

Shiel A.E., Weis D., Cossa D. and Orians K.J. (2013) Determining provenance of marine metal pollution in French bivalves using $\mathrm{Cd}, \mathrm{Zn}$ and $\mathrm{Pb}$ isotopes. Geochimica et Cosmochimica Acta, 121, 155-167.

Shields W.R., Goldich S.S., Garner E.L. and Murphy T.J. (1965)

Natural variations in the abundance ratio and the atomic weight of copper. Journal of Geophysical Research, 70, 479-491.

Sossi P.A., Halverson G.P., Nebel O. and Eggins S.M. (2015)

Combined separation of $\mathrm{Cu}$, Fe and $\mathrm{Zn}$ from rock matrices and improved analytical protocols for stable isotope determination. Geostandards and Geoanalytical Research, 39, 129-149.

Tanzi R.E., Petrukhin K., Chernov l., Pellequer J.L, Wasco W., Ross B., Romano D.M., Parano E., Pavone L. and Brzustowicz L.M. (1993)

The Wilson disease gene is a copper transporting ATPase with homology to the Menkes disease gene. Nature Genetics, 5, 344 
references

Télouk P., Puisieux A., Fujii T., Balter V.P., Bondanese V., Morel A.-P., Clapisson G., Lamboux A. and Albarède F. (2015)

Copper isotope effect in serum of cancer patients. A pilot study. Metallomics, 7, 299-308.

Townley B., Luca R., Soto C., López L., Muñoz M., Garcia M., Aguilar G., Puig A., Mathur R. and Reich M. (2015) Hydromorphic dispersion of metals and geochemical signatures through transported overburden at the Inca de Oro porphyry copper district, northern Chile. Chilean Geological Congress, 14, 187-190.

Uauy R., Olivares M. and Gonzalez M. (1998)

Essentiality of copper in humans. The American Journal of Clinical Nutrition, 67, 952S-959S.

Van Heghe L., Deltombe O., Delanghe J., Depypere H. and Vanhaecke F. (2014)

The influence of menstrual blood loss and age on the isotopic composition of $\mathrm{Cu}, \mathrm{Fe}$ and $\mathrm{Zn}$ in human whole blood. Journal of Analytical Atomic Spectrometry, 29, 478-482

Verma S.P., Rosales-Rivera M., Díaz-González L. and Quiroz-Ruiz A. (2017)

Improved composition of Hawaiian basalt BHVO-1 from the application of two new and three conventional recursive discordancy tests. Turkish Journal of Earth Sciences, 26, 331-353.
Walker E.C., Cuttitta F. and Senffle F.E. (1958)

Some natural variations in the relative abundance of copper isotopes. Geochimica et Cosmochimica Acta, 15, 183-194.

Yang L., Tong S., Zhou L., Hu Z., Mester Z. and Meija J. (2018)

A critical review on isotopic fractionation correction methods for accurate isotope amount ratio measurements by MC-ICP-MS. Journal of Analytical Atomic Spectrometry, 33, 1849-1861.

Yruela I. (2005)

Copper in plants. Brazilian Journal of Plant Physiology, 17, 145-156.

\section{Supporting information}

The following supporting information may be found in the online version of this article:

Appendix S1. Uncertainty estimation for ${ }^{65} \mathrm{Cu}$.

This material is available from: http://onlinelibrary.wiley. com/doi/10.1111/ggr.12315/abstract (This link will take you to the article abstract). 